\title{
Heat Capacity and Thermodynamic Property of Lithium Pentaborate Pentahydrate
}

\author{
Wanjing Cui, ${ }^{1}$ Long Li, ${ }^{1}$ Yafei Guo $\mathbb{D}^{1,2}$ Sisi Zhang, ${ }^{1}$ and Tianlong Deng ${ }^{1}{ }^{1}$ \\ ${ }^{1}$ Tianjin Key Laboratory of Marine Resources and Chemistry, College of Chemical Engineering and Material Science, \\ Tianjin University of Science and Technology, Tianjin 300457, China \\ ${ }^{2}$ College of Chemistry and Materials Science, Northwest University, Xian 710127, China
}

Correspondence should be addressed to Yafei Guo; guoyafei@tust.edu.cn and Tianlong Deng; tldeng@tust.edu.cn

Received 2 October 2017; Accepted 18 December 2017; Published 17 January 2018

Academic Editor: Elena Gomez

Copyright (C) 2018 Wanjing Cui et al. This is an open access article distributed under the Creative Commons Attribution License, which permits unrestricted use, distribution, and reproduction in any medium, provided the original work is properly cited.

\begin{abstract}
The heat capacity of lithium pentaborate pentahydrate has been measured using an adiabatic calorimeter at the temperature from 297 to $375 \mathrm{~K}$. No phase transition and thermal anomalies were observed. The molar heat capacity of $\mathrm{LiB}_{5} \mathrm{O}_{8} \cdot 5 \mathrm{H}_{2} \mathrm{O}$ can be expressed as $C_{p, m}\left(\mathrm{~J} \cdot \mathrm{mol}^{-1} \cdot \mathrm{K}^{-1}\right)=396.79376+35.87528\left[T-\left(T_{\max }+T_{\min }\right) / 2\right] /\left[\left(T_{\max }-T_{\min }\right) / 2\right]+0.16494\left\{\left[T-\left(T_{\max }+T_{\min }\right) / 2\right] /\left[\left(T_{\max }-T_{\min }\right) / 2\right]\right\}^{2}$ $+8.3083\left\{\left[T-\left(T_{\max }+T_{\min }\right) / 2\right] /\left[\left(T_{\max }-T_{\min }\right) / 2\right]\right\}^{3}$, where $T$ is the temperature in Kelvin, $T_{\max }=375 \mathrm{~K}$, and $T_{\min }=297 \mathrm{~K}$. The thermodynamic functions of $\left(H_{T}-H_{298.15}\right),\left(S_{T}-S_{298.15}\right)$, and $\left(G_{T}-G_{298.15}\right)$ of $\mathrm{LiB}_{5} \mathrm{O}_{8} \cdot 5 \mathrm{H}_{2} \mathrm{O}$ are obtained via the molar heat capacity at the temperature of $5 \mathrm{~K}$ intervals.
\end{abstract}

\section{Introduction}

Studies of alkali borates have attracted much interest in recent years because some of these compounds especially the alkali pentaborates show significant physical interest, such as nonlinear optical behavior [1]. The $\left[\mathrm{B}_{5} \mathrm{O}_{10}\right]^{2-}$ boron oxycyclic structure of the alkali metal pentaborate crystal contains the $\mathrm{BO}_{3}$ group, which has a strong macro frequency effect and can be used in the field of nonlinear optical materials [2]. In addition, the lithium pentaborate $\left(\mathrm{LiB}_{5} \mathrm{O}_{8} \cdot 5 \mathrm{H}_{2} \mathrm{O}\right)$ also can be used in special glass, lubricating oil additives, and production of boron oxide [3, 4].

Heat capacity is one of the important parameters of thermodynamic properties to optimize the producing process. And reliable calculation of such thermodynamic functions of entropy, enthalpy, and Gibbs free energy requires data on heat capacity [5]. Furthermore, heat capacity is inherent characteristic of crystals, closely related to the specific features of their composition and structure. To better understand the industrial application of $\mathrm{LiB}_{5} \mathrm{O}_{8} \cdot 5 \mathrm{H}_{2} \mathrm{O}$ and perform the corresponding theoretical studies, the thermodynamic properties of this compound are essential. Li et al. [6] reported the standard molar enthalpy of formation of $\mathrm{LiB}_{5} \mathrm{O}_{8} \cdot 5 \mathrm{H}_{2} \mathrm{O}$. Ge et al. [7] determined the physicochemical properties of $\mathrm{LiB}_{5} \mathrm{O}_{8}$ solutions, including the density, viscosity, conductivity, and $\mathrm{pH}$. However, there is no data reported on the heat capacity of $\mathrm{LiB}_{5} \mathrm{O}_{8} \cdot 5 \mathrm{H}_{2} \mathrm{O}$ in the literature. In this paper, the heat capacity of $\mathrm{LiB}_{5} \mathrm{O}_{8} \cdot 5 \mathrm{H}_{2} \mathrm{O}$ has been determined using an adiabatic calorimeter in the temperature range from 297 to $375 \mathrm{~K}$, and the values of the thermodynamic functions, heat capacity, entropy, enthalpy, and Gibbs free energy, were calculated at temperature $5 \mathrm{~K}$ intervals.

\section{Experimental}

2.1. Synthesis. The chemical of $\mathrm{LiB}_{5} \mathrm{O}_{8} \cdot 5 \mathrm{H}_{2} \mathrm{O}$ was synthesized in our laboratory according to the phase diagram of system $\mathrm{Li}_{2} \mathrm{O}-\mathrm{B}_{2} \mathrm{O}_{3}-\mathrm{H}_{2} \mathrm{O}$ [8]. Certain amounts of $\mathrm{H}_{3} \mathrm{BO}_{3}$ and $\mathrm{LiOH} \cdot \mathrm{H}_{2} \mathrm{O}$ were dissolved in the quantificational deionized water under stirring for $24 \mathrm{~h}$ at $333.15 \mathrm{~K}$. Then, the product was filtered by suction filtration and washed three times with deionized water and absolute ethyl alcohol, respectively. Finally, the samples were dried until the weight was constant and stored in the desiccators for use.

2.2. Characterization and Analytical Methods. The synthesized chemical of $\mathrm{LiB}_{5} \mathrm{O}_{8} \cdot 5 \mathrm{H}_{2} \mathrm{O}$ was identified by X-ray powder diffraction (PERSEE XD-3 polycrystalline X-ray 


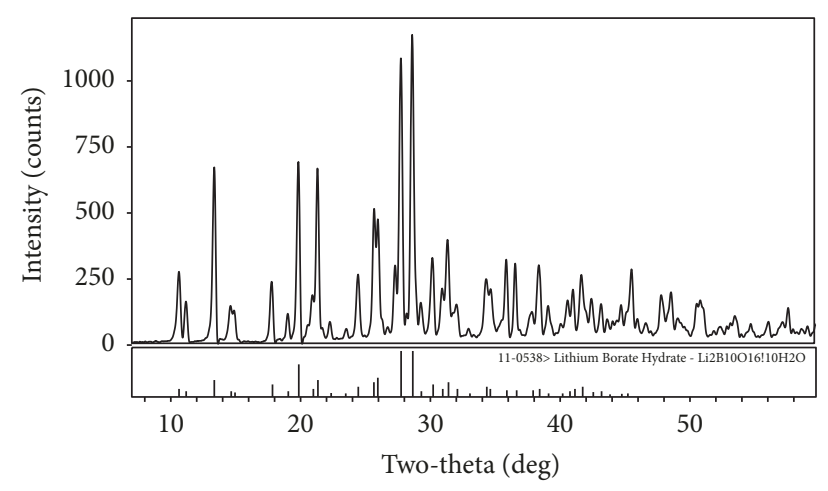

FIgURE 1: The X-ray diffraction pattern of $\mathrm{LiB}_{5} \mathrm{O}_{8} \cdot 5 \mathrm{H}_{2} \mathrm{O}$.

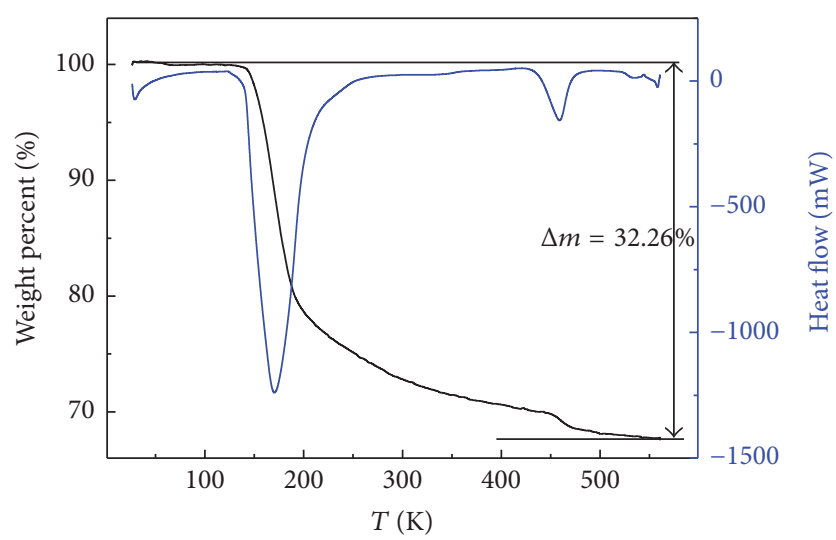

FIgURE 2: The TG curve of $\mathrm{LiB}_{5} \mathrm{O}_{8} \cdot 5 \mathrm{H}_{2} \mathrm{O}$.

diffractometer with $\mathrm{Cu}-\mathrm{K} \alpha$ radiation at $\left.4^{\circ} \mathrm{min}^{-1}\right)$ and thermogravimetric (TG) (performed on a SETARAM LABSYS thermal analyzer under argon atmosphere with a heating rate of $\left.10 \mathrm{~K} \mathrm{~min}^{-1}\right)$. The X-ray powder pattern of the synthesized $\mathrm{LiB}_{5} \mathrm{O}_{8} \cdot 5 \mathrm{H}_{2} \mathrm{O}$ in Figure 1 shows that the diffraction peaks on patterns correspond well in position, indicating the phase purity of the synthesized samples. The weight loss of $32.26 \%$ from the TG curve in Figure 2 corresponds to the loss of five water molecules and can be compared with the calculated value of $32.26 \%$.

The $\mathrm{B}_{2} \mathrm{O}_{3}$ concentration was analyzed using gravimetric method with sodium hydroxide standard solution in the presence of mixture indicators of methyl red plus phenolphthalein and the excessive mannitol conditions, and the standard uncertainty $u\left(\mathrm{BO}_{2}{ }^{-}\right)$was 0.0005 in mass fraction [9]. The lithium ion content was measured by inductively coupled plasma optical emission spectrometer (Prodigy, Leman Corporation, America) with precision of $\pm 0.5 \%$. The crystallized water content was calculated through subtraction. The chemical analytical result of $\mathrm{LiB}_{5} \mathrm{O}_{8} \cdot 5 \mathrm{H}_{2} \mathrm{O}$ is listed in Table 1 .

2.3. Adiabatic Calorimetry and Experiment Method. Heat capacity measurements were carried out in a high-precision SETARAM BT 2.15 adiabatic calorimeter. The BT 2.15 calorimeter comprises a calorimetric chamber, electrical or pneumatic peripherals, and the liquid nitrogen supply. The calorimetric chamber can receive the heat capacity cell, which
TABLE 1: Chemical analytical result of lithium pentaborate pentahydrate in mass fraction.

\begin{tabular}{lcccc}
\hline & $\mathrm{Li}_{2} \mathrm{O}$ & $\mathrm{B}_{2} \mathrm{O}_{3}$ & $\mathrm{H}_{2} \mathrm{O}$ & $n\left(\mathrm{Li}_{2} \mathrm{O}: \mathrm{B}_{2} \mathrm{O}_{3}: \mathrm{H}_{2} \mathrm{O}\right)$ \\
\hline Experimental & 0.0538 & 0.6262 & 0.3200 & $1.00: 4.99: 9.87$ \\
Theoretical & 0.0536 & 0.6239 & 0.3226 & $1.00: 5.00: 10.00$ \\
\hline
\end{tabular}

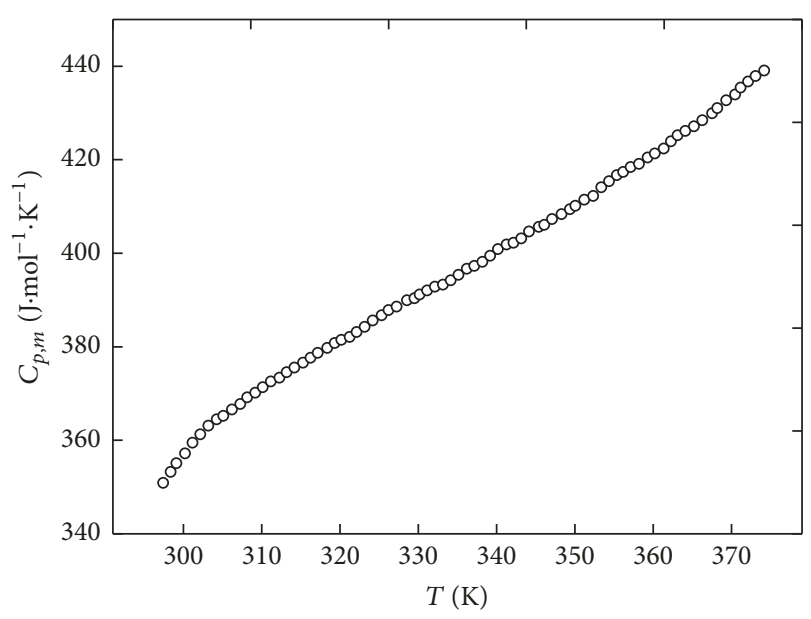

FIgURE 3: Experimental molar heat capacity of $\mathrm{LiB}_{5} \mathrm{O}_{8} \cdot 5 \mathrm{H}_{2} \mathrm{O}$ in the range of 297 to $375 \mathrm{~K}$.

is provided with a syringe for sample introduction. The sample mass used for the heat capacity measurement was $8877.74 \mathrm{mg}$. The performance of this calorimetric apparatus has been verified by measuring the heat capacity of $\mathrm{KCl}$ where the average result is $0.6877 \mathrm{~J} \cdot \mathrm{g}^{-1} \cdot \mathrm{K}^{-1}$ in seven times and the deviation of the results is 0.0007 , compared with the reference data of $0.6879 \mathrm{~J} \cdot \mathrm{g}^{-1} \cdot \mathrm{K}^{-1}[10]$. The heat capacity $C_{p, m}$ of the sample was measured ranging from 297 to $375 \mathrm{~K}$ by an adiabatic continuous heating technique with a heating rate of $0.1 \mathrm{~K} / \mathrm{min}$

\section{Results and Discussion}

3.1. Heat Capacity. According to the experimental method, the heat capacity $C_{p}$ of $\mathrm{LiB}_{5} \mathrm{O}_{8} \cdot 5 \mathrm{H}_{2} \mathrm{O}$ was measured using the adiabatic calorimeter from 297 to $375 \mathrm{~K}$ with standard uncertainty $0.05 \mathrm{~J} \cdot \mathrm{mol}^{-1} \cdot \mathrm{K}^{-1}$, and the result of the molar heat capacity of $\mathrm{LiB}_{5} \mathrm{O}_{8} \cdot 5 \mathrm{H}_{2} \mathrm{O}$ is shown in Table 2 and Figure 3.

In Figure 3, it is shown that the heat capacity of $\mathrm{LiB}_{5} \mathrm{O}_{8} \cdot 5 \mathrm{H}_{2} \mathrm{O}$ sample increases smoothly with the increasing of temperature in the range between 297 and $375 \mathrm{~K}$ without any phase transition and thermal anomaly.

On the basis of the Debye Law [11], the molar heat capacity of $\mathrm{LiB}_{5} \mathrm{O}_{8} \cdot 5 \mathrm{H}_{2} \mathrm{O}$ determined in this work has been fitted and shown in (1). On the basis of (1), the molar heat capacity of $\mathrm{LiB}_{5} \mathrm{O}_{8} \cdot 5 \mathrm{H}_{2} \mathrm{O}$ at $298.15 \mathrm{~K}$ can be obtained as $354.54 \mathrm{~J} \cdot \mathrm{mol}^{-1} \cdot \mathrm{K}^{-1}$.

$$
\begin{aligned}
& C_{p, m}\left(\mathrm{~J} \cdot \mathrm{mol}^{-1} \cdot \mathrm{K}^{-1}\right) \\
& \quad=396.79376+35.87528 \frac{\left[T-\left(T_{\max }+T_{\min }\right) / 2\right]}{\left[\left(T_{\max }-T_{\min }\right) / 2\right]}
\end{aligned}
$$


TABLE 2: Molar heat capacity of $\mathrm{LiB}_{5} \mathrm{O}_{8} \cdot 5 \mathrm{H}_{2} \mathrm{O}$ (molecular mass $M=$ $278.99 \mathrm{~g} \mathrm{~mol}^{-1}$ ).

\begin{tabular}{|c|c|c|c|c|c|}
\hline$T / K$ & $\begin{array}{c}C_{p, m} \\
\mathrm{~J} \cdot \mathrm{mol}^{-1} \cdot \mathrm{K}^{-1}\end{array}$ & $T / K$ & $\begin{array}{c}C_{p, m} \\
\mathrm{~J} \cdot \mathrm{mol}^{-1} \cdot \mathrm{K}^{-1}\end{array}$ & $T / K$ & $\begin{array}{c}C_{p, m} \\
\mathrm{~J} \cdot \mathrm{mol}^{-1} \cdot \mathrm{K}^{-1}\end{array}$ \\
\hline 297.44 & 350.85 & 324.19 & 385.60 & 350.08 & 410.17 \\
\hline 298.38 & 353.23 & 325.32 & 386.75 & 351.22 & 411.46 \\
\hline 299.13 & 355.08 & 326.23 & 387.85 & 352.36 & 412.27 \\
\hline 300.21 & 357.20 & 327.24 & 388.59 & 353.39 & 414.08 \\
\hline 302.18 & 361.25 & 328.58 & 389.95 & 354.39 & 415.41 \\
\hline 303.19 & 363.14 & 329.53 & 390.38 & 355.37 & 416.69 \\
\hline 304.28 & 364.46 & 330.19 & 391.17 & 356.16 & 417.34 \\
\hline 305.11 & 365.22 & 331.15 & 392.06 & 357.13 & 418.45 \\
\hline 306.21 & 366.60 & 332.13 & 392.83 & 358.21 & 419.13 \\
\hline 307.28 & 367.77 & 333.16 & 393.24 & 359.31 & 420.45 \\
\hline 308.16 & 369.14 & 334.14 & 394.20 & 360.23 & 421.34 \\
\hline 309.21 & 370.16 & 335.16 & 395.38 & 361.34 & 422.37 \\
\hline 310.16 & 371.33 & 336.21 & 396.66 & 362.26 & 423.94 \\
\hline 311.18 & 372.58 & 337.16 & 397.30 & 363.12 & 425.24 \\
\hline 312.29 & 373.40 & 338.21 & 398.18 & 364.13 & 426.12 \\
\hline 313.20 & 374.52 & 339.19 & 399.46 & 365.21 & 427.13 \\
\hline 314.18 & 375.55 & 340.17 & 400.85 & 366.28 & 428.43 \\
\hline 315.31 & 376.60 & 341.29 & 401.88 & 367.53 & 429.91 \\
\hline 316.24 & 377.63 & 342.16 & 402.22 & 368.19 & 431.01 \\
\hline 317.18 & 378.66 & 343.15 & 403.16 & 369.33 & 432.70 \\
\hline 318.40 & 379.72 & 344.15 & 404.66 & 370.49 & 433.92 \\
\hline 319.35 & 380.80 & 345.41 & 405.60 & 371.18 & 435.44 \\
\hline 320.18 & 381.48 & 346.10 & 406.09 & 372.12 & 436.70 \\
\hline 321.26 & 382.09 & 347.10 & 407.30 & 373.09 & 437.91 \\
\hline 322.15 & 383.11 & 348.30 & 408.37 & 374.18 & 439.08 \\
\hline 323.16 & 384.23 & 349.39 & 409.37 & & \\
\hline
\end{tabular}

Note. Standard uncertainty of temperature $u(T)=0.01 \mathrm{~K}$, and the molar heat capacity $u\left(C_{p, m}\right)=0.05 \mathrm{~J} \cdot \mathrm{mol}^{-1} \cdot \mathrm{K}^{-1}$.

$$
\begin{aligned}
& +0.16494\left\{\frac{\left[T-\left(T_{\max }+T_{\min }\right) / 2\right]}{\left[\left(T_{\max }-T_{\min }\right) / 2\right]}\right\}^{2} \\
& +8.3083\left\{\frac{\left[T-\left(T_{\max }+T_{\min }\right) / 2\right]}{\left[\left(T_{\max }-T_{\min }\right) / 2\right]}\right\}^{3},
\end{aligned}
$$

where $T$ is the absolute temperature in Kelvin, $T_{\max }$ is the upper temperature $(375 \mathrm{~K})$, and $T_{\min }$ is the lower temperature $(297 \mathrm{~K})$. The deviations between the experimental and the fitted values are within 0.005 and shown in Figure 4.

3.2. Enthalpy, Entropy, and Gibbs Free Energy. The thermodynamic functions of $\mathrm{LiB}_{5} \mathrm{O}_{8} \cdot 5 \mathrm{H}_{2} \mathrm{O}$ relative to the standard status, that is, $298.15 \mathrm{~K}$ and $0.1 \mathrm{MPa}$, can be derived based on the following thermodynamic equations:

$$
\begin{aligned}
H_{T}-H_{298.15} & =\int_{298.15}^{T} C_{p, m} \mathrm{~d} T, \\
S_{T}-S_{298.15} & =\int_{298.15}^{T}\left[\frac{C_{p, m}}{T}\right] \mathrm{d} T,
\end{aligned}
$$

TABLE 3: Calculated molar heat capacities and thermodynamic functions of $\mathrm{LiB}_{5} \mathrm{O}_{8} \cdot \mathrm{H}_{2} \mathrm{O}$.

\begin{tabular}{lcccc}
\hline$T / \mathrm{K}$ & $\begin{array}{c}\mathrm{C}_{p, m} \\
\mathrm{~J} \cdot \mathrm{mol}^{-1} \cdot \mathrm{K}^{-1}\end{array}$ & $\begin{array}{c}\mathrm{H}_{T}-\mathrm{H}_{298.15} \\
\mathrm{~kJ} \cdot \mathrm{mol}^{-1}\end{array}$ & $\begin{array}{c}S_{T}-S_{298.15} \\
\mathrm{~J} \cdot \mathrm{mol}^{-1} \cdot \mathrm{K}^{-1}\end{array}$ & $\begin{array}{c}G_{T}-G_{298.15} \\
\mathrm{~kJ} \cdot \mathrm{mol}^{-1}\end{array}$ \\
\hline 298.15 & 354.54 & 0 & 0 & 0 \\
300 & 357.28 & 0.6590 & 2.2035 & -0.0020 \\
305 & 364.21 & 2.465 & 8.17 & -0.0280 \\
310 & 370.49 & 4.303 & 14.15 & -0.0838 \\
315 & 376.23 & 6.172 & 20.13 & -0.1695 \\
320 & 381.53 & 8.068 & 26.10 & -0.2851 \\
325 & 386.50 & 9.990 & 32.06 & -0.4305 \\
330 & 391.25 & 11.936 & 38.01 & -0.6057 \\
335 & 395.87 & 13.906 & 43.93 & -0.8105 \\
340 & 400.48 & 15.898 & 49.83 & -1.0449 \\
345 & 405.18 & 17.915 & 55.72 & -1.3088 \\
350 & 410.08 & 19.955 & 61.59 & -1.6021 \\
355 & 415.27 & 22.020 & 67.45 & -1.9247 \\
360 & 420.87 & 24.112 & 73.30 & -2.2766 \\
365 & 426.98 & 26.234 & 79.15 & -2.6577 \\
370 & 433.70 & 28.387 & 85.01 & -3.0681 \\
375 & 441.14 & 30.576 & 90.89 & -3.5079 \\
\hline
\end{tabular}

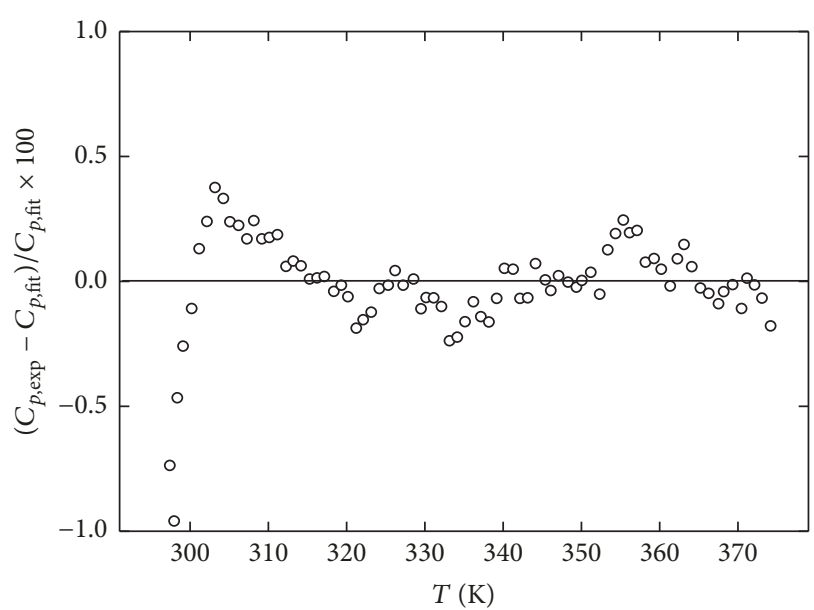

FIgURE 4: Plot of deviations of experimental data from fitted.

$$
G_{T}-G_{298.15}=\int_{298.15}^{T} C_{p, m} \mathrm{~d} T-T \int_{298.15}^{T}\left[\frac{C_{p, m}}{T}\right] \mathrm{d} T .
$$

The results of the molar heat capacity and thermodynamic functions of $\left(H_{T}-H_{298.15}\right),\left(S_{T}-S_{298.15}\right)$, and $\left(G_{T}-\right.$ $\left.G_{298.15}\right)$ are obtained and listed in Table 3 with a temperature of $5 \mathrm{~K}$ interval. From the entropy function data in Table 3, it is shown that the molar heat capacity and the changes of enthalpy $\left(H_{T}-H_{298.15}\right)$ and entropy $\left(S_{T}-S_{298.15}\right)$ are increased with the increasing of temperature from $298.15 \mathrm{~K}$ to $375 \mathrm{~K}$ and the changes of free energy $\left(G_{T}-G_{298.15}\right)$ are just the opposite. 


\section{Conclusions}

The heat capacity of $\mathrm{LiB}_{5} \mathrm{O}_{8} \cdot 5 \mathrm{H}_{2} \mathrm{O}$ was measured using an adiabatic calorimeter at temperatures from 297 to $375 \mathrm{~K}$, and it did not contain anomalous contributions at the experimental temperature regions. The molar heat capacity of $\mathrm{LiB}_{5} \mathrm{O}_{8} \cdot 5 \mathrm{H}_{2} \mathrm{O}$ obeys a polynomial of $C_{p, m}\left(\mathrm{~J} \cdot \mathrm{mol}^{-1} \cdot \mathrm{K}^{-1}\right)=$ $396.79376+35.87528\left[T-\left(T_{\max }+T_{\min }\right) / 2\right] /\left[\left(T_{\max }-T_{\min }\right) / 2\right]$ $+0.16494\left\{\left[T-\left(T_{\max }+T_{\min }\right) / 2\right] /\left[\left(T_{\max }-T_{\min }\right) / 2\right]\right\}^{2}+$ $8.3083\left\{\left[T-\left(T_{\max }+T_{\min }\right) / 2\right] /\left[\left(T_{\max }-T_{\min }\right) / 2\right]\right\}^{3}$. The molar heat capacity and thermodynamic functions of $\left(\mathrm{H}_{T}-\mathrm{H}_{298.15}\right)$, $\left(S_{T}-S_{298.15}\right)$, and $\left(G_{T}-G_{298.15}\right)$ for $\mathrm{LiB}_{5} \mathrm{O}_{8} \cdot 5 \mathrm{H}_{2} \mathrm{O}$ are obtained for the first time.

\section{Conflicts of Interest}

The authors declare that they have no conflicts of interest.

\section{Acknowledgments}

The authors gratefully acknowledge financial support from the National Natural Science Foundation of China (U1607123 and 21773170), the Yangtze Scholars and Innovative Research Team in Chinese University (IRT-17R81), the Postdoctoral Science Foundation (2016M592827), and the Laboratory Foundation of Chinese Universities (SY2015018).

\section{References}

[1] Y. Wu, T. Sasaki, S. Nakai, A. Yokotani, H. Tang, and C. Chen, "CsB ${ }_{3} \mathrm{O}_{5}$ : a new nonlinear optical crystal," Applied Physics Letters, vol. 62, no. 21, pp. 2614-2615, 1993.

[2] S. S. Zhang, L. Li, Y. F. Guo, and T. L. Deng, "Study on the syntheses of alkalis pentaborates," Journal of Salt Science and Chemical Industry, vol. 46, no. 6, pp. 31-34, 2017.

[3] L. J. Jiang and G. S. Wang, "Synthesis of potassium pentaborate," Journal of Shenyang University of Chemical Technology, vol. 23, no. 3, pp. 222-225, 2009.

[4] Rio Tinto American boron Asia Technology Center, "Application of borate in oil and gas field development," in Proceedings of the Twentieth Seminar of the Development and Application on Chinese Oil and Gas Field Chemicals, pp. 55-57, Beijing, China, March 2014.

[5] M. A. Bespyatov, I. S. Chernyaikin, V. N. Naumov, P. A. Stabnikov, and N. V. Gelfond, "Low-temperature heat capacity of $\mathrm{Al}\left(\mathrm{C}_{11} \mathrm{H}_{19} \mathrm{O}_{2}\right)_{3}$," Thermochimica Acta, vol. 596, pp. 40-41, 2014.

[6] J. Li, B. A. Li, and S. Gao, "Thermochemistry of hydrated lithium borates," The Journal of Chemical Thermodynamics, vol. 30, no. 6, pp. 681-688, 1998.

[7] H. W. Ge, C. H. Fang, Y. Fang et al., "Study on physical and chemical properties of $\mathrm{LiB}_{5} \mathrm{O}_{8}$ solution," Journal of Salt Lake Research, vol. 23, no. 001, pp. 44-50, 2015.

[8] W. T. Reburn and W. A. Gale, "The system lithium oxide-boric oxide-water," The Journal of Physical Chemistry, vol. 59, no. 1, pp. 19-24, 1955.

[9] Qinghai institute of salt lakes of CAS, Analytical Methods of Brines and Salts, Chinese Science Press, Beijing, China, 2nd edition, 1988.

[10] J. G. Speight, Lange's Handbook of Chemistry, McGraw-Hill, New York, NY, USA, 16th edition, 2005.
[11] M. R. Bissengaliyeva, D. B. Gogol, and N. S. Bekturganov, "Low temperature measurements of the heat capacity and thermodynamic functions of pseudo-malachite $\mathrm{Cu}_{5}\left(\mathrm{PO}_{4}\right)_{2}(\mathrm{OH})_{4}$," Thermochimica Acta, vol. 532, pp. 139-144, 2012. 

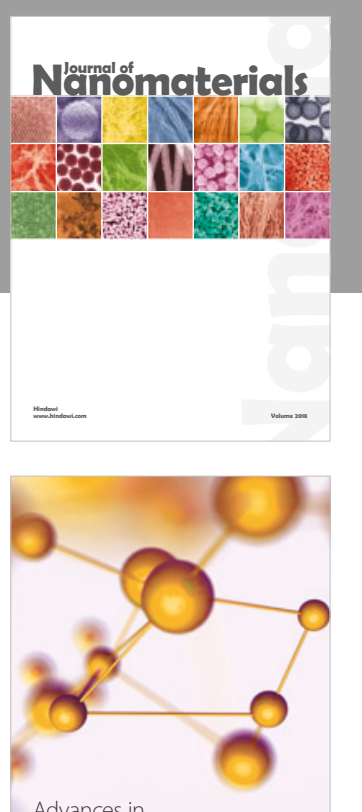

Physical Chemistry
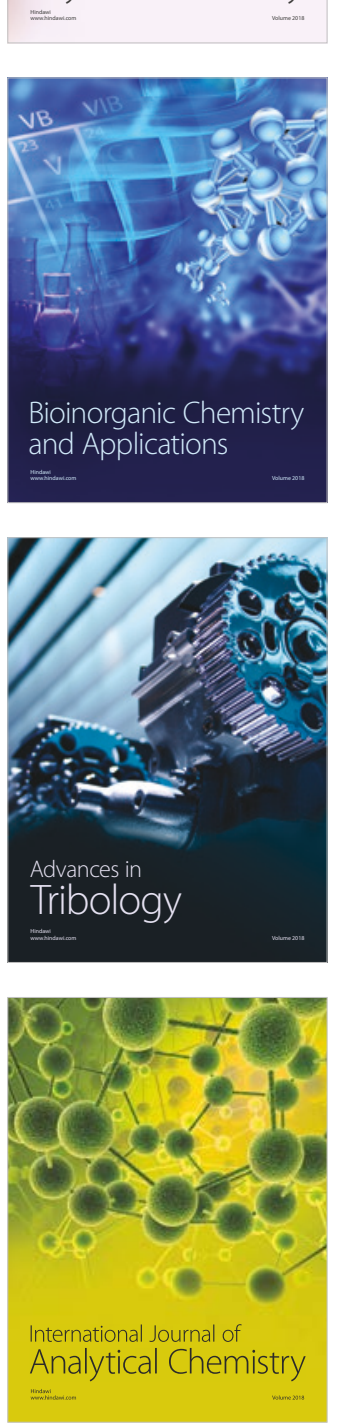

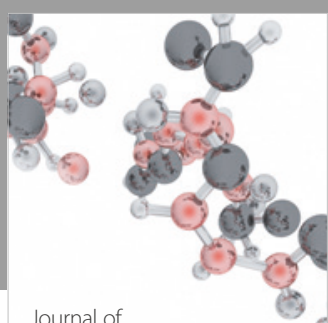

Analytical Methods

in Chemistry

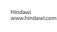

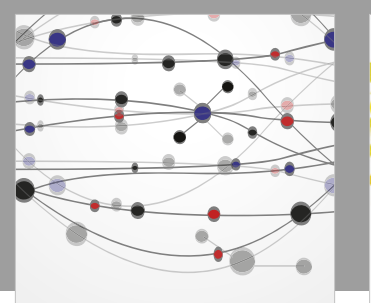

The Scientific World Journal

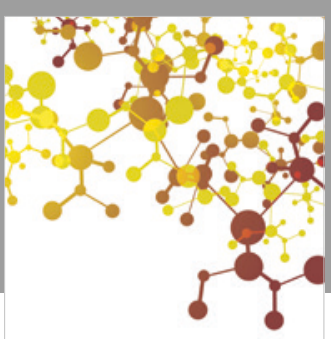

Journal of

Applied Chemistry
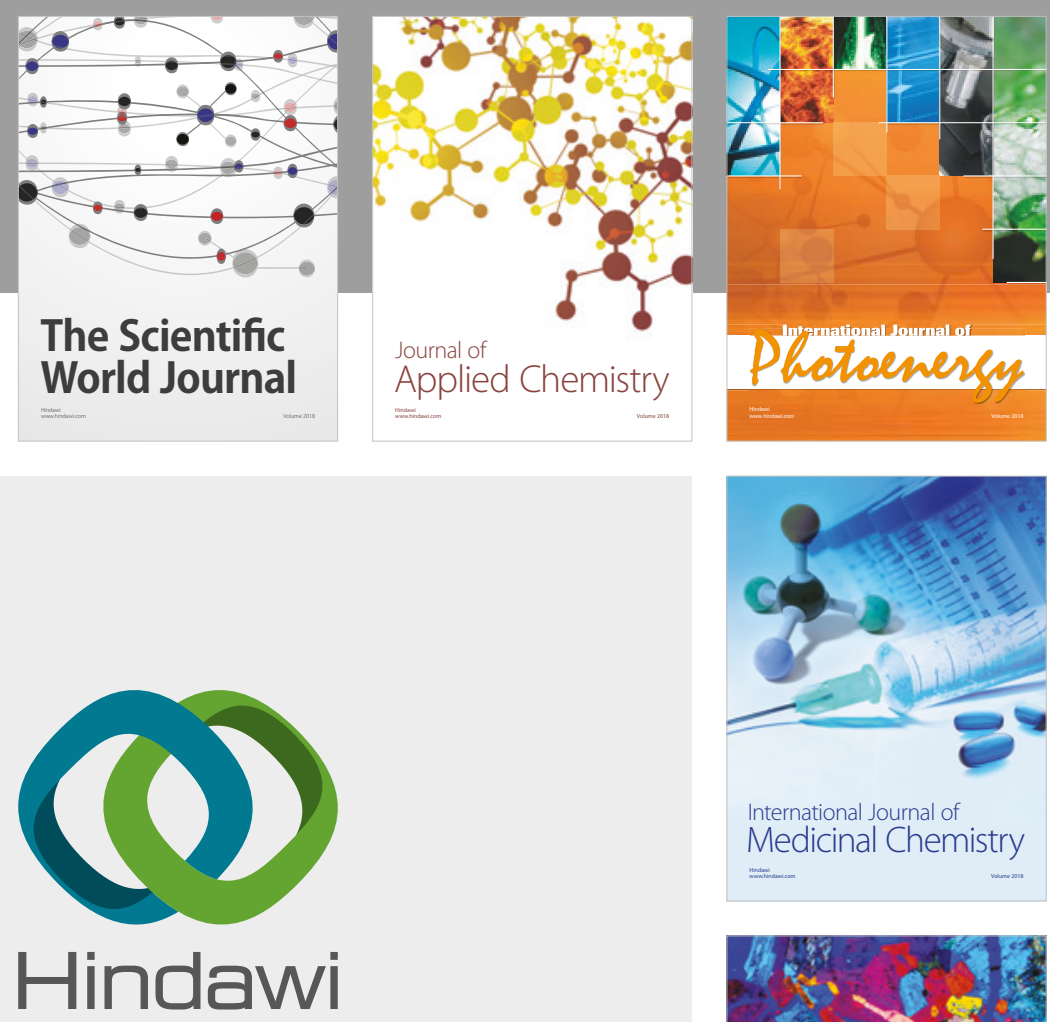

Submit your manuscripts at

www.hindawi.com
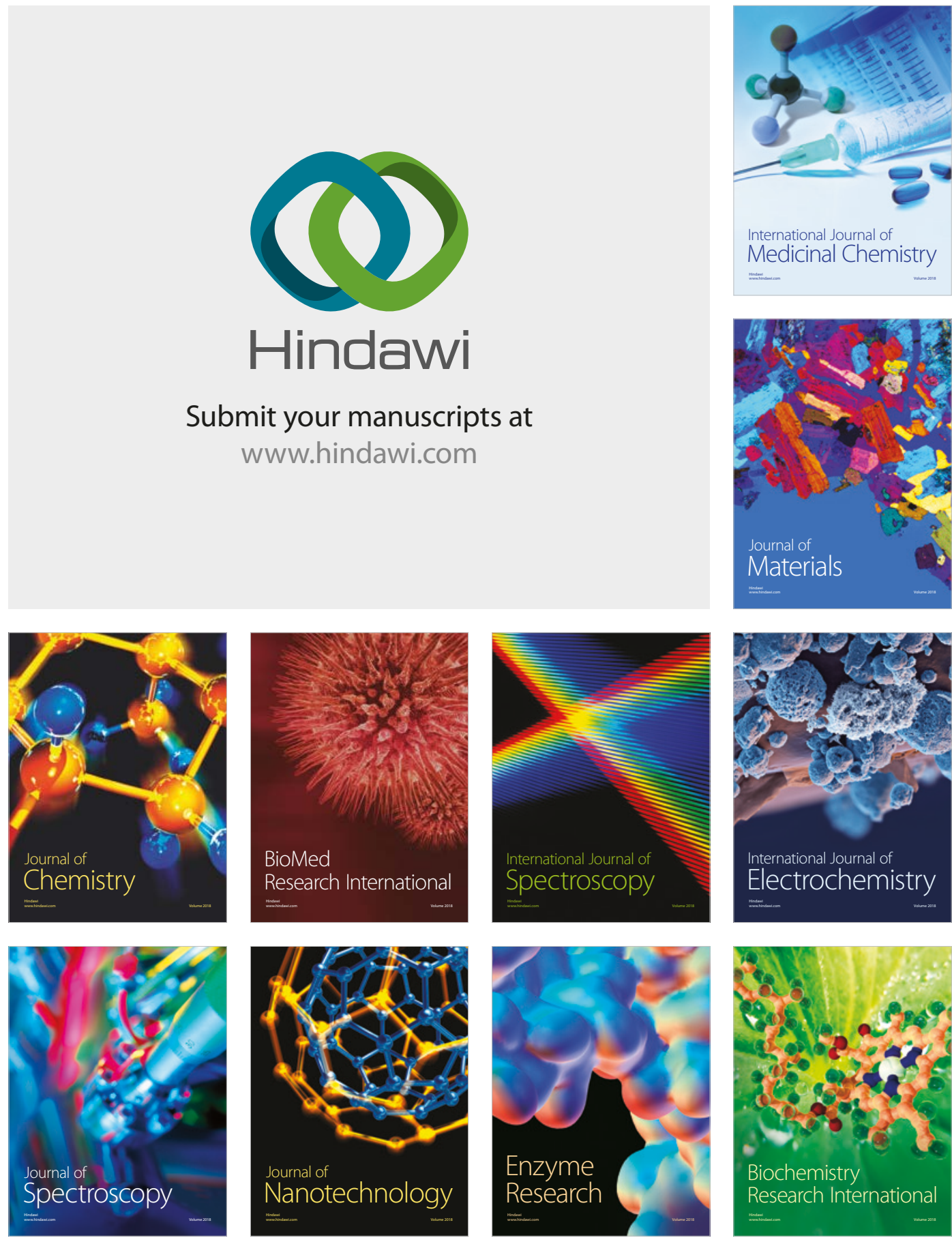
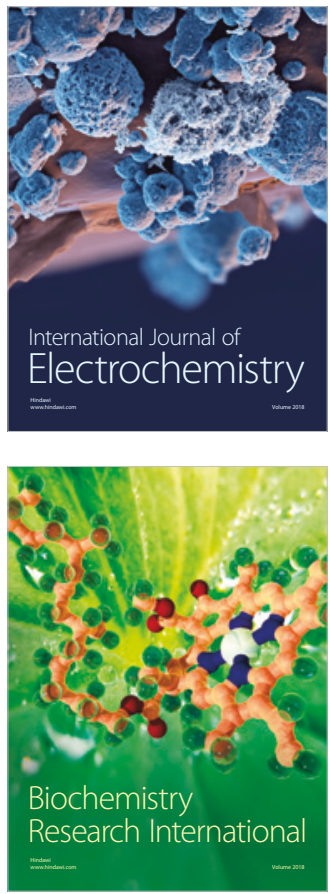